\title{
Екстракорпоральне поширення кісткового цементу після перкутанної кіфопластики
}

\author{
С. М. Лисенко ${ }^{1}$, Р. Ю. Ілюк ${ }^{1}$, А. Л. Литвиненко ${ }^{1}$, О. В. Клименко ${ }^{1,2}$, А. В. Ашихмін \\ В. Й. Шуба 2 О. М. Возняк ${ }^{1,2}$ \\ ${ }^{1}$ Клінічна лікарня «Феофанія», м. Київ, \\ ${ }^{2}$ Національна медична академія післядипломної освіти імені П. Л. Шупика, м. Київ, \\ ${ }^{3}$ Національний інститут раку, м. Київ

\section{Extracorporeal expansion of a bone cement after percutaneous kyphoplasty}

\author{
S. M. Lysenko ${ }^{1}$, R. Yu. Ilyuk ${ }^{1}$, A. L. Lytvynenko ${ }^{1}$, O. V. Klymenko ${ }^{1,2}$, A. V. Ashykhmin ${ }^{3}$, \\ V.J. Shuba ${ }^{2}$, O. M. Voznyak ${ }^{1,2}$ \\ ${ }^{1}$ Clinical Hospital «Feofaniya», Kyiv, \\ ${ }^{2}$ Shupyk National Medical Academy of Postgraduate Education, Kyiv, \\ ${ }^{3}$ National Cancer Institute, Kyiv
}

\section{Реферат}

Мета. Вивчити особливості та клінічні прояви екстракорпорального поширення (ЕКП) кісткового цементу (КЦ) після перкутанної балонної кіфопластики (КП) з приводу остеопенічних та остеолітичних уражень хребців.

Матеріали і методи. Проведено ретроспективне дослідження щодо 50 пацієнтів після КП з приводу остеопоротичних компресійних переломів хребців (24 пацієнти, прооперовано 51 хребець), метастатичних уражень (7 пацієнтів і 10 хребців), мієломної хвороби (4 пацієнти і 10 хребців) та агресивних гемангіом (15 пацієнтів і 23 хребці). ЕКП КЦ оцінювали за даними післяопераційної мультиспіральної комп’ютерної томографії окремо у венозні судини та через дефекти кіркового шару хребців.

Результати. ЕКП КЦ виявлено на 52 (50,5\%) із 103 оперованих рівнів та в півнепарну вену (у 1 пацієнта) і гілки легеневої артерії (у 2 пацієнтів). Найчастіше ЕКП КЦ реєстрували після КП з приводу метастатичних уражень хребців, переважно в основно-хребцеві вени. ЕКП КЦ в міжхребцеві диски виявлено тільки після КП з приводу остеопоротичних переломів (15,7\% спостережень). Спостерігали клінічні прояви ЕКП КЦ в хребтовий канал як у вени, так і через дефекти кіркового шару хребців.

Висновки. КП є безпечним методом укріплення хребців, уражених різноманітною патологією. Клінічно значущі прояви ЕКП КЦ спостерігали лише в разі потрапляння КЦ в хребтовий канал як у венозні сплетення, так і через дефекти кіркового шару хребців. ЕКП КЦ не слід розглядати як самостійне ускладнення КП.

Ключові слова: перкутанна балонна кіфопластика; екстракорпоральне поширення кісткового цементу; ускладнення

\section{Abstract}

Objective. To study the peculiarities and clinical signs of extracorporeal expansion (ECE) of a bone cement (BC) after percutaneous balloon kyphoplasty (KP), performed for the osteopenia and the osteolysis vertebral affections.

Materials and methods. Retrospective investigation was conducted in 50 patients after KP, performed for the osteoporosis compression vertebral fractures (24 patients, 51 vertebra operated), metastatic affections ( 7 patients and 10 vertebra), the myeloma disease ( 4 patients and 10 vertebra) and aggressive hemangiomas (15 patients and 23 vertebra). ECE BC was estimated in accordance to data of postoperative multi-spiral computeric tomography, while separately - into venous vessels and through defects in vertebral cortical layer.

Results. ECE BC was revealed on 52 (50.5\%) of 103 operated levels and on level of v. hemiazygos (in 1 patient) and the pulmonary artery branch (in 2 patients). Most frequently ECE BC were registered after KP, made for metastatic affections of vertebra, mainly into basilo-vertebral veins. ECE BC into intervertebral discs were revealed only after KP, performed for the osteoporosis fractures in (15.7\%) observations. Clinical signs of ECE BC, penetrating into vertebral channel into veins, as well as through defects in vertebral cortical layer, were observed.

Conclusion. KP constitutes a secure method of strengthening of vertebra, which are affected by various pathology. Clinically significant signs of ECE of BC were observed while its entry inside vertebral channel - into venous plexus, as well as through defects in a cortical bone layer of vertebra. ECE BC must not be regarded as independent complication of KP.

Keywords: percutaneous balloon kyphoplasty; extracorporeal expansion of a bone cement; complication.

Концепцію перкутанної балонної КП розробив Mark Reiley як удосконалення пункційної вертебропластики (ВП) шляхом роздування балонного ущільнювача, покликаного забезпечити редукцію компресійного перелому і зменшити ризики ЕКП КЦ та зумовлених ним ускладнень, і вона була схвалена FDA. Перше таке втручання виконане для лікування патологічного остеопоротичного перелому в 1998 р. [1]. Багатьма дослідниками доведена однаково висока ефективність ВП та КП з приводу остеопенічних та остеолітичних уражень хребців [2, 3], а у пацієнтів з агресивними гемангіомами КП є одним із методів вибору хірургічного лікування [4]. Основним та найчастішим ускладнен- 
ням цементопластики вважають ЕКП КЦ. У перших дослідженнях щодо ВП було отримано низьку (до 11\%) загальну частоту ЕКП КЦ, проте застосування мультиспіральної комп'ютерної томографії (МСКТ) у багатоцентровому відкритому рандомізованому контрольованому дослідженні VERTOS II [5] показало, що частота ЕКП КЦ після ВП з приводу остеопоротичних компресійних переломів хребців (КПХ) істотно вища - 80\%. Після КП з приводу як остеопоротичних, так і остеолітичних уражень частота ЕКП КЦ була значно нижчою, ніж після ВП, і становила від 4 до 39\% [6], проте ці показники грунтувалися переважно на даних рентгенографії як основного методу виявлення ЕКП КЦ. Також часто дослідники вказували на безсимптомний перебіг ЕКП КЦ або на тимчасовий характер симптомів навіть у разі потрапляння КЦ в хребтовий канал.

A. J. Khanna і співавтори та Н. Semaan і співавтори [6, 7] дійшли висновку про можливість порівняння частоти ЕКП КЦ після застосування цементопластики в лікуванні різних остеолітичних та остеопенічних уражень хребців, a H. G. Palm і співавтори [8] довели найвищу чутливість МСКТ для виявлення ЕКП КЦ порівняно з іншими методами інтраскопічних досліджень.

Незважаючи на те що клінічно значущі прояви ЕКП КЦ виникають рідко, проте можливість розвитку мієлопатії, радикулопатії та емболії легеневих артерій цементом зумовлює актуальність проблеми та необхідність з'ясування причин і пошуку способів уникнення ЕКП КЦ і його ускладнень.

Мета дослідження: виявлення особливостей та клінічних проявів ЕКП КЦ після КП у пацієнтів з остеопенічними (остеопороз) та остеолітичними (мієломна хвороба, метастатичні пухлини - Mts та гемангіоми) ураженнями хребців, що проявлялися больовим синдромом.

\section{Матеріали і методи дослідження}

Проведено ретроспективний аналіз щодо 50 пацієнтів, яким у 2012 - 2017 рр. в Центрі нейрохірургії клінічної лікарні «Феофанія» ДУС виконана КП з приводу локального больового синдрому, зумовленого гострими остеопоротичними КПХ, пухлинними ураженнями, мієломною хворобою та агресивними гемангіомами. Показаннями до виконання КП з приводу остеопоротичних КПХ (тип A1 за AOSpine) [9] був стійкий больовий синдром, нечутливий до консервативного лікування впродовж 2 - 3 тижнів. За наявності пухлин враховували можливість виконання втручання, збереженість кіркового шару хребця навколо хребтового каналу, ризики ЕКП КЦ, неможливість радикального видалення новоутворення (наприклад, у разі множинних метастатичних уражень), тобто ми радше враховували можливість виконання хірургічного втручання, ніж тривалість аналгетичної терапії чи необхідність призначення опіатів.

Вік пацієнтів становив від 37 до 82 років, в середньому 64 роки. Жінок було 36 (72\%), чоловіків - 14 (28\%). Остеопоротичні КПХ діагностовані у 24 пацієнтів, Mts у 7, мієломна хвороба - у 4, агресивні гемангіоми - у 15. Всього оперовано 103 хребці: 3 приводу остеопоротичних компресійних переломів - 51, мієломної хвороби 10, Mts - 19, агресивних гемангіом - 23.
Всі втручання виконані із застосуванням одноплощинної C-арки (Radionics Vision Vista та Siemens Arcadis Varic C-Arm), флюорографії під час введення троакарів і балонів та флюороскопічного контролю етапів роздування балонів і введення КЦ. У всіх пацієнтів використовували систему Kyphon (Medtronic) та КЦ з високою в'язкістю на основі поліметилметакрилату (ПММА). Із двостороннього транспедикулярного доступу оперовано 83 (80,6\%) хребці, одностороннього - 20 (19,4\%) хребців. Односторонній доступ застосували тільки на двох рівнях при остеопоротичних переломах, переважно при односторонніх гемангіомах та метастатичних ураженнях хребців.

Усім пацієнтам з пухлинними ураженнями виконана біопсія, діагноз підтверджений гістологічно.

На наступний день після втручання всім пацієнтам проводили МСКТ та рентгенографію оперованих та суміжних хребців. Ретроспективну оцінку всіх інтраскопічних даних здійснював незалежний рентгенолог. Сумнівні ознаки ЕКП КЦ розцінювали на користь його наявності.

Виділені дві основних групи ЕКП КЦ, а саме: по венозних судинах та через дефекти кіркового шару хребця. Якщо виявляли поширення КЦ по венозних судинах, виділяли його потрапляння в переднє зовнішнє хребтове венозне сплетення (ПЗХВС), основно-хребцеві вени, переднє внутрішнє хребтове венозне сплетення (ПВХВС), корінцеві вени, сегментарні вени, порожнисту вену/півнепарну вену, в гілки легеневих артерій [5]. У разі ЕКП КЦ через дефекти кіркового шару хребця, що могли бути зумовлені або переломами, або хірургічними маніпуляціями, виділяли його потрапляння в паравертебральні м'які тканини до переду від тіла хребця; паравертебрально латерально, в тому числі в клубово-поперековий м'яз; паравертебрально до заду - у м'яз-випрямляч хребта; вертикально - в суміжні міжхребцеві диски (МХД) та в хребтовий канал.

Всі патерни ЕКП КЦ оцінювали для кожного оперованого хребця окремо, окрім потрапляння КЦ в півнепарну вену та в гілки легеневої артерії, коли верифікація окремого хребця не завжди можлива.

\section{Результати}

Нами проаналізовані дані всіх післяопераційних МСКТ та рентгенограм на рівні уражених хребців, а також всіх інших інтраскопічних обстежень (магнітно-резонансної томографіï, рентгенографії органів грудної порожнини, позитронно-емісійної комп'ютерної томографіi), що були призначені або як рутинні періодичні обстеження, або з метою діагностики інших захворювань у пацієнтів, яким була виконана КП.

Прискіпливо проаналізувавши дані післяопераційних МСКТ, ми виявили ЕКП КЦ на 52 (50,5\%) із 103 оперованих рівнів (див. таблицю). У 1 пацієнта КЦ було виявлено в півнепарній вені, у 2 пацієнтів - в гілках легеневої артерії.

Найвищу частоту ЕКП КЦ спостерігали після КП з приводу метастатичних уражень хребта (на 68,7\% оперованих рівнів). Після КП з приводу остеопоротичних переломів та мієломної хвороби частота ЕКП КЦ було приблизно однаковою - 52,9 і 50\% відповідно, а після КП з приводу агресивних гемангіом - найнижчою та становила 30,4\%. 


\begin{tabular}{|c|c|c|c|c|c|c|c|c|}
\hline \multicolumn{9}{|c|}{ Розподіл екстракорпорального поширення кісткового цементу залежно від патології } \\
\hline \multirow{3}{*}{ Розподіл ЕКП КЦ } & \multicolumn{8}{|c|}{ Патологія та кількість оперованих хребів } \\
\hline & \multicolumn{2}{|c|}{$\begin{array}{l}\text { Остеопороз } \\
(n=51)\end{array}$} & \multicolumn{2}{|c|}{$\begin{array}{l}\text { Мієломна хвороба } \\
(n=10)\end{array}$} & \multicolumn{2}{|c|}{$\begin{array}{l}\text { Метастази } \\
(n=19)\end{array}$} & \multicolumn{2}{|c|}{$\begin{array}{l}\text { Гемангіоми } \\
\quad(n=23)\end{array}$} \\
\hline & абс. & $\%$ & абс. & $\%$ & абс. & $\%$ & абс. & $\%$ \\
\hline ПЗХВС & 6 & 11,7 & 3 & 30 & 3 & 15,8 & 3 & 13 \\
\hline Основно-хребцеві вени & 1 & 1,9 & & & & & & \\
\hline ПВХВВС & 2 & 3,9 & & & & & & \\
\hline Корінцеві вени & 2 & 3,9 & & & 1 & 5,3 & & \\
\hline Сегментарні вени & & & & & 3 & 15,8 & & \\
\hline Півнепарна вена/легенева артерія & 1 & 1,9 & 1 & 10 & 1 & 5,3 & & \\
\hline До переду від хребця & 1 & 1,9 & & & 2 & 10,7 & 1 & 4,3 \\
\hline Латерально від хребця & 3 & 5,9 & 1 & 10 & 3 & 15,8 & 1 & 4,3 \\
\hline Хребтовий канал & 1 & 1,9 & & & & & 1 & 4,3 \\
\hline До заду від хребтового стовпа & 2 & 3,9 & & & & & 1 & 4,3 \\
\hline МХД & 8 & 15,7 & & & & & & \\
\hline Всього ... & 27 & 52,9 & 5 & 50 & 13 & 68,7 & 7 & 30,4 \\
\hline
\end{tabular}

Клінічні прояви ЕКП КЦ ми відмічали лише у разі потрапляння КЦ в хребтовий канал. ЕКП КЦ в хребтовий канал через дефекти кіркового шару хребців спостерігали на 2 оперованих рівнях. В одному спостереженні проявом ЕКП КЦ був полірадикулопатичний синдром, який, незважаючи на медикаментозне лікування, залишився стійким. Ще в одному спостереженні після операції з приводу агресивної гемангіоми об'єм ПММА в хребтовому каналі був незначним і не викликав клінічних симптомів.

Для ЕКП КЦ у вени хребтового каналу характерними були симптоми у вигляді минущого радикулярного больового синдрому, які виявляли тільки тоді, коли КЦ локалізувався в корінцевих венах. КЦ у гілках легеневої артерії виявлено у 2 пацієнтів, у півнепарній вені - у 1. У всіх цих спостереженнях ЕКП КЦ було безсимптомним.

У 1 пацієнта з тяжким остеопорозом через 2 дні після втручання виникла тромбоемболія гілок лівої легеневої артерії. Виконана балонна КП на 2 рівнях, проте жодних ознак ЕКП КЦ у вени або в легеневі артерії не виявлено.

Поширення ПММА в МХД ми спостерігали лише після КП з приводу остеопоротичних переломів. Нові компресійні переломи суміжних хребців виявлені лише у 1 пацієнтки з тяжким перебігом остеопорозу.

\section{Обговорення}

Під ЕКП КЦ ми розуміли будь-яке його потрапляння за межі кіркового шару хребця. Загальна частота ЕКП КЦ залежить в тому числі від методу інтраскопічної візуалізації $[5,8]$. Окремі дослідники проводили МСКТ тільки у разі підозри на ЕКП КЦ [7]. Ми проводили МСКТ всім досліджуваним пацієнтам після балонної КП. На нашу думку, це підвищує об'єктивізацію отриманих результатів. Наші результати були порівнянними з даними досліджень, проведених за подібною методикою [11]. J. S. Yеот і співавтори [12] вперше запропонували класифікацію ЕКП КЦ за трьома напрямками - через систему основно-хребцевої вени, сегментарні вени та через дефекти кіркового шару хребця. Наявність КЦ в основно-хребцевій вені, строго кажучи, не можна розглядати як ЕКП КЦ, оскіль- ки вена знаходиться ще в межах хребця, проте будь-яке потрапляння КЦ у венозні судини потенційно може призводити до асоційованої з цементом тромбоемболії легеневої артерії (ТЕЛА), так само ЕКП КЦ через дефекти кіркового шару хребця може як не мати клінічних проявів узагалі, так і призводити до катастрофічних наслідків через механічну компресію та термічні ураження нервових структур. Ми вважаємо, що запропонована нами класифікація ЕКП КЦ максимально повно відображає наші та описані в літературі клінічні спостереження, враховує можливі ризики виникнення емболії легеневих артерій і водночас є простою.

Ми спостерігали всього 4 пацієнти з мієломами, у них оперовано 10 хребців, тому репрезентативність наших даних не можна вважати високою.

У пацієнтів з метастатичними ураженнями хребта частота ЕКП КЦ була найвищою. Також найчастіше (26,4\%) в наших спостереженнях відмічали ознаки ЕКП КЦ у венозні сплетення, пов'язані з основно-хребцевою веною, що вірогідно відображає особливості та інтенсивність венозного відтоку за наявності цих ураженнь.

ЕКП КЦ у корінцеві вени зумовлювало нетривалий радикулярний біль та потребувало додаткового призначення аналгетиків. Разом з тим виконання цементопластики з приводу гемангіом вважають фактором ризику ЕКП КЦ у венозні судини, проте в наших спостереженнях ми не відмічали жодних симптомів поширення КЦ у ПЗХВС. Ми можемо пояснити це тромбуванням судин гемангіоми при тривалому роздуванні балонних ущільнювачів в тілі хребця.

Поширення ПММА в МХД після КП з приводу остеопоротичних переломів можна пояснити наявністю переломів замикальних пластин практично у всіх пацієнтів з гострим КПХ. Поширення КЦ в МХД може призводити до виникнення переломів суміжних хребців [13], проте ми зафіксували нові переломи тільки в одному спостереженні. В 4 спостереженнях поширення КЦ в суміжні МХД дані інтраскопічних обстежень отримані через 2 роки і більше, проте нових переломів не було виявлено. На нашу думку, 
переломи суміжних хребців з більшою вірогідністю можуть бути зумовлені тяжкістю остеопорозу або іншими патологічними чинниками, а не виконанням цементопластики або ЕКП КЦ в МХД.

Ми спостерігали лише безсимптомне поширення КЦ в легеневі артерії. Високу вірогідність безсимптомного перебігу потрапляння КЦ в легеневі артерії підтверджують й інші дослідники [14]. Зафіксована ТЕЛА вірогідно стала наслідком соматичних захворювань, а не ЕКП КЦ, хоча окремі автори описували серед можливих причин ТЕЛА жирову емболію та емболію кістковим мозком [15]. Разом 3 тим можна припустити наявність ризику пухлинної емболії під час роздування балонів у ході виконання операцій з приводу метастатичних пухлин або мієломної хвороби, проте в літературі подібні ускладнення не описані. Кількість даних спостережень недостатня для того, щоб робити узагальнення, проте може свідчити про важливість враховування параметрів об'ємного венозного кровотоку та венозного тиску в паравертебральних сплетеннях під час виконання КП, а також введення КЦ під неперервним флюороскопічним контролем для вчасного виявлення мінімальних ознак ЕКП.

Клінічні прояви поширення КЦ в хребтовий канал через венозні судини спостерігали рідше, і вони були менш стійкими, ніж прояви витікання КЦ через дефекти кіркового шару хребця. На нашу думку, це зумовлено значно тіснішим контактом між ПММА та твердою мозковою оболонкою корінців і спинного мозку у разі поширення через дефекти, а відтак і вищим ризиком локальних неврологічних ускладнень.

Для попередження ЕКП КЦ запропонована велика кількість способів: виконання флебографії перед введенням КЦ [16], використання методики «яєчної шкаралупи» [17], проведення штучної вентиляції з позитивним тиском кінця видиху під час введення КЦ [18] тощо, кожен з яких має свою практичну та історичну цінність. На нашу думку, значущими факторами попередження ЕКП КЦ є виконання всіх технічних нюансів КП, а саме: коректне розташування балона в тілі хребця, застосування цементів з високою в'язкістю, контрольоване введення КЦ та обмеження об'єму введеного КЦ зменшують ризик ЕКП КЦ [19].

Незважаючи на високу загальну частоту ЕКП КЦ, його клінічно значущі ускладнення виникли тільки у 3 пацієнтів, а стійкими вони були лише у 1 пацієнта.

\section{Висновки}

1. КП є безпечним методом укріплення хребців, уражених різноманітною патологією.

2. Клінічно значущі ускладнення ЕКП КЦ спостерігали лише у разі його потрапляння в хребтовий канал як у венозні сплетення, так і через дефекти кіркового шару хребців.

3. ЕКП КЦ не слід розглядати як самостійне ускладнення КП.

\section{Підтвердження}

\section{Інформація про фінансування.}

Джерелом фінансування наукової роботи і публікації статті є приватні особи.
Інформація про внесок кожного учасника.

С. М. Лисенко -збір та аналіз даних; Р. Ю. Ілюк - концепція та дизайн дослідження, збір та аналіз даних, написання тексту; А. Л. Литвиненко -збір та аналіз даних; О. В. Клименко -збір та аналіз даних, написання та редагування тексту; А. В. Ашихмін -аналіз інтраскопічних досліджень, В. Й. Шуба - аналіз отриманих даних, написання тексту; О. М. Возняк -концепція та дизайн дослідження, написання та редагування тексту.

Всі автори прочитали та схвалили остаточний варіант рукопису.

Конфлікт інтересів. Автори Лисенко С. М. та Ілюк Р. Ю. отримували від компанії Medtronic фінансову підтримку для участі в симпозіумах.

\section{Згода на публікацію}

Всі автори дали згоду на публікацію цього рукопису.

\section{References}

1. Belkoff SM, Mathis JM, Fenton DC, Scribner RM, Reiley ME, Talmadge $\mathrm{K}$. An ex vivo biomechanical evaluation of an inflatable bone tamp used in the treatment of compression fracture. Spine (Phila Pa 1976). 2001 Jan 15;26(2):151-6. PMID: 11154534.

2. van Tilburg CWJ, Groeneweg JG, Stronks DL, Huygen FJ. Effectiveness of Balloon Kyphoplasty in Patients with Painful Vertebral Compression Fractures. J Pain Relief. 2018 Jan;7(3):323. doi: 10.4172/21670846.1000323

3. Health Quality Ontario. Vertebral Augmentation Involving Vertebroplasty or Kyphoplasty for Cancer-Related Vertebral Compression Fractures: A Systematic Review. Ont Health Technol Assess Ser. 2016 May 1;16(11):1-202. PMID: 27298655.

4. Jiang L, Liu XG, Yuan HS, Yang SM, Li J, Wei F, et al. Diagnosis and treatment of vertebral hemangiomas with neurologic deficit: a report of 29 cases and literature review. Spine J. 2014 Jun 1;14(6):944-54. doi: 10.1016/j.spinee.2013.07.450.

5. Venmans A, Klazen CA, van Rooij WJ, de Vries J, Mali WP, Lohle PN. Postprocedural CT for perivertebral cement leakage in percutaneous vertebroplasty is not necessary - results from VERTOS II. Neuroradiology. 2011 Jan;53(1):19-22.doi: 10.1007/s00234-010-0705-6.

6. Khanna AJ, Reinhardt MK, Togawa D, Lieberman IH. Functional outcomes of kyphoplasty for the treatment of osteoporotic and osteolytic vertebral compression fractures. Osteoporos Int. 2006;17(6):81726. 16518574.

7. Semaan H, Obri T, Bazerbashi M, Paull D, Liu X, Sarrouj M, Elgafy H. Clinical outcome and subsequent sequelae of cement extravasation af ter percutaneous kyphoplasty and vertebroplasty: a comparative review. Acta Radiol. 2018 Jul;59(7):861-8. doi: 10.1177/0284185117732599.

8. Palm HG, Riesner HJ, Lang P, Haentzsch M, Friemert B, Hackenbroch C. Diagnostic Accuracy of Fluoroscopy, Radiography, and Computed Tomography in Detecting Cement Leakage in Kyphoplasty. J Neurol Surg A Cent Eur Neurosurg. 2018 Nov;79(6):502-10. doi: 10.1055/s0038-1641734.

9. Vaccaro AR, Oner C, Kepler CK, Dvorak M, Schnake K, Bellabarba C, et al.; AOSpine Spinal Cord Injury \& Trauma Knowledge Forum. AOSpine thoracolumbar spine injury classification system: fracture description, neurological status, and key modifiers. Spine (Phila Pa 1976). 2013 Nov 1;38(23):2028-37. doi:10.1097/BRS.0b013e3182a8a381.

10. Théron J, Moet J. Spinal Phlebography:Lumbar and Cervical Techniques. Berlin: Springer-Verlag; 1978. 168 p.

11. Lee IJ, Choi AL, Yie MY, Yoon JY, Jeon EY, Koh SH, et al. CT evaluation of local leakage of bone cement after percutaneous kyphoplasty and vertebroplasty. Acta Radiol. 2010 Jul;51(6):649-54. doi: $10.3109 / 02841851003620366$.

12. Yeom JS, Kim WJ, Choy WS, Lee CK, Chang BS, Kang JW. Leakage of cement in percutaneous transpedicular vertebroplasty for painful osteoporotic compression fractures. J Bone Joint Surg Br. 2003 Jan;85(1):839. PMID: 12585583. 
13. Jamjoom B, Patel S, Bommireddy R, Klezl Z. Impact of the quantity of intradiscal cement leak on the progression of intervertebral disc degeneration. Ann R Coll Surg Engl. 2017 Sep;99(7):529-33. doi: 10.1308/ resann.2017.0083.

14. Ignacio JMF, Ignacio KHD. Pulmonary Embolism from Cement Augmentation of the Vertebral Body. Asian Spine J. 2018 Apr;12(2):380-7. doi: 10.4184/asj.2018.12.2.380.

15. Takahashi S, Kitagawa H, Ishii T. Intraoperative pulmonary embolism during spinal instrumentation surgery. A prospective study using transoesophageal echocardiography. J Bone Joint Surg Br. 2003 Jan;85(1):90-4. doi: 10.1302/0301-620X.85B1.13172.

16. Gaughen JR Jr, Jensen ME, Schweickert PA, Kaufmann TJ, Marx WF, Kallmes DF. Relevance of antecedent venography in percutaneous vertebroplasty for the treatment of osteoporotic compression fractures. AJNR Am J Neuroradiol. 2002 Apr;23(4):594-600.
17. Greene DL, Isaac R, Neuwirth M, Bitan FD. The eggshell technique for prevention of cement leakage during kyphoplasty. J Spinal Disord Tech. 2007 May; 20(3):229-32. doi: 10.1097/01.bsd.0000211276.76024.3.

18. Gonschorek O, Hauck S, Weiß T, Bühren V. Percutaneous vertebral augmentation in fragility fractures - indications and limitations. Eur J Trauma Emerg Surg. 2017 Feb;43(1):9-17. doi: 10.1007/s00068016-0753-7.

19. Robinson Y, Tschöke SK, Stahel PF, Kayser R, Heyde CE. Complications and safety aspects of kyphoplasty for osteoporotic vertebral fractures: a prospective follow-up study in 102 consecutive patients. Patient Saf Surg. 2008 Jan 15;2:2. doi: 10.1186/1754-9493-2-2.

Отримана 08.10.2018 